\title{
The Effectiveness of Snakes and Ladders Game for the Social-Emotional Development of Children in the Pandemic Time Covid 19
}

\author{
Novia Wahyu Wardhani ${ }^{1 *}$, Agustinus Sugeng Priyanto ${ }^{2}$, Nugraheni Arumsari ${ }^{3}$, \\ Erisandi Arditama ${ }^{4}$, Winda N L ${ }^{5}$
}

1,2,3,4,5 Faculty of Social Science, Semarang State University

*Corresponding author. Email: noviawahyu@mail.unnes.ac.id

\begin{abstract}
The purpose of this study is to measure the effectiveness of the game of snakes and ladders for children's socialemotional development. The research was conducted from January-April 2021 in Green Village, Ngijo, Gunungpati. The target is children aged 7-12 years. The method used is mixed. Data obtained from questionnaires distributed before and after the game of snakes and ladders with all players as respondents, totaling 12 children. Questionnaires are used to assess how the child feels after playing snake and ladder. Observations were made before the game took place to determine the child's initial condition, during the game to see the child's changes directly, and several months after the game took place to find out whether the child's condition had changed. Interviews were conducted with 12 informants who are parents of children aged 7-12 years. Documentation is a portrait of children's activities during play. The validity of the data was done through the triangulation of techniques and triangulation of sources. Data analysis using data analysis with an interactive model. The result is that this snake and ladder game is quite effective for children's social and emotional development because the snake and ladder contain the value of unity and integrity, playing outdoors, and playing in groups. These games can stimulate children to cooperate, respect each other, and tolerate them. Children also increasingly understand that in social relationships it is important to have respect, tolerance, cooperation, and care.
\end{abstract}

Keywords: Snakes and Ladders, Development, Social, Emotional.

\section{INTRODUCTION}

The problem of covid 19 is not only a problem that occurs in Indonesia but all over the world. Fears of the development of viruses and interpersonal transmission led to the launch of a national social distance program [1], [2], [3] The most severe problem is the problem suffered by children between the ages of 3-12 years. They have lost the future if this is not addressed immediately. Starting from the optimal learning process, can not play with his friends socially outside the house, limited wiggle room that causes various heaps of stress, fat, and saturation.

Covid 19, which has been around for more than a year, has not yet been resolved. This makes isolation longer. Longer isolation presents a greater risk to delayed development of the child [4], [5]. Whereas all potential children develop at this time including the potential of social and emotional intelligence [6]. Based on various studies in the field of neurology have proven that $50 \%$ of children's intelligence is formed within the first 4 years. After the child turns 8 years old his brain development reaches $80 \%$ and at the age of 18 years reaches $100 \%$. This is that the development that occurs within the first 4 years is as great as the development that occurs in the next 14 years, so this period is a critical period for the child, where the development obtained by the child is very influential to the development of the next period to adulthood.

This social and emotional development problem in Ngijo, Gunungpati, Semarang, especially in Green Village, is faced by elementary school-age children between the ages of 7-12 years. They face a period where the effects of this covid have led to reduced social feelings and a lack of emotional control [7]. Evidence in previous research many parents complain about changes 
in their children where the child becomes irritable, moody, dependent on gadgets, unconcerned, and lazy.

Many things affect the socio-emotional development of the child. These factors include technology [8], parenting patterns and relationships with parents [9], peer interaction [10], and inherited traits [11]. Technology is said to be influential because the covid period has changed society from the use of technology a little more. Especially in children where learning activities at school, activities in the playing community, and communication with parents are replaced by the use of gadgets. It is also influenced by parenting patterns and parental relationships with children. Parents in the middle class in the covid period show more neglect towards the development of children because of stress with sudden social and economic changes. So, when the child plays with a gadget and silent then, he will free his son to play until sometimes does not remember the time. Covid 19 has also made children's interactions in their social environment such as between peers, parents, and the community becomes disrupted when they need examples, examples, situations, and good conditions for the development of social and emotional intelligence.

According to Morin, socialization is an important process in a child's development because, in that way, children learn skills that influence daily interactions with others. Dr. Barbara Nosal, Ph.D., LMFT, LADC, a chief clinical officer at Newport Academy also said during a period of social development, when a child loses the opportunity to build these skills, it potentially delays their socio-emotional development. This unexpected impact that caused anticipation of its development was not rapid. This socio-emotional development is hard to see. Based on observations on February 20, 2021 children tend to go undetected through social-emotional changes unless there are trigger problems. For example, when they are prohibited from playing with their gadgets, the angry ones that are issued tend to be aggressive such as shouting, slamming, and hitting.

This anticipation cannot be done independently by the child, because at this time cannot control his psyche independently, of course, parents, teachers [12], and the community that can control it. The development of socialization is related to emotions [13]. When his social development is limited then he can understand little about emotions and how to manage them. For example, he saw at home his parents were always fighting, his mom was screaming and his dad was hitting. Because the covid 19 pandemic restricts their movement to socialize outside then what is recorded if there is a conflict is shouting and hitting and attitudes and behaviors are reflected only from people who are at home.

One way to restore a child's social-emotional development is to give back the child's playroom with his friends outside the house. Open space with fresh air that includes physical and social activities. Like an outdoor snake and ladder game. Snakes and ladders are favored by children because they can play outside with friends, have care, and gain a lot of knowledge and gifts to restore the spirit of togetherness and provide a new understanding of the values of tolerance and diversity. Based on this background, this study wants to examine how effective the game of snakes and ladders is for the social and emotional development of children.

\section{METHOD}

This research is social research using a mix of methods. This research took place from 2020 to 2021 in Green Village, Ngijo, Gunungpati, Semarang City. The data was obtained from observations made in March and October 2020 then continued in January 2021 on the social and emotional development of children. The second data is obtained from interviews with parents. The informant, 12, is a parent of a child who participates in a game of snakes and ladders. Children who follow the game of snakes are bored children and experience changes at home during the pandemic covid 19. Further data is obtained from the documentation at the time of the implementation of the game of snakes and ladders. The latest data was obtained from a questionnaire distributed to 12 children who participated in a game of snakes and ladders about the changes they felt and the benefits they gained. This poll is open.

The validity of the data is done by triangulation of techniques and triangulation of sources. Trianggulasi technique is done by comparing data from several techniques to obtain valid results about research answers. The second way is to compare data from one source to another to avoid data bias. Questionnaire questions are made through FGD research members consisting of academics, practitioners, and various experts numbering 8 people. The collected data is then analyzed and concluded.

\section{RESULTS AND DISCUSSION}

Effectiveness is usually characterized and measured by the degree of achievability of goals whereas effectiveness is a success. The outdoor snakes and ladders game is a game of snakes and ladders conducted outdoors. Snakes and Ladders game is a medium of children's play in an open space that aims to develop social and emotional attitudes and behaviors where children for almost a year their interaction with the outside is limited.

The $5 \mathrm{~m} \times 5 \mathrm{~m}$ game is played in groups. Not only are snakes, ladders, boxes, and numbers found in this game, but there are also other games in each box. Some of the challenges on each box require them to be solved in groups. Like installing puzzles, guessing styles, and show work. Other games in this snakes and ladders exist as a 
useful complement to build relationships between individuals within a group. Games or surprise questions in each box are also made to add insight and knowledge about the value of Diversity and Diversity in Indonesia. The shape of the snake ladder is like the picture below.

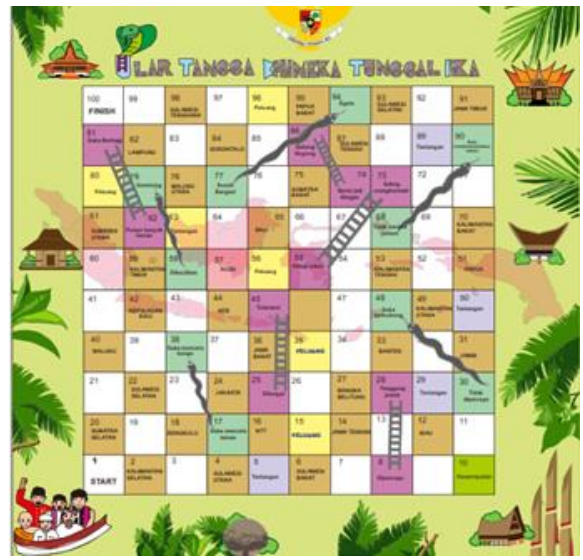

Figure 1 Snakes and Ladders Games

While the form of the question corresponds to the box that is visited like a provincial box where the question adjusts the things in the province. An example of the question can be seen in the image below.

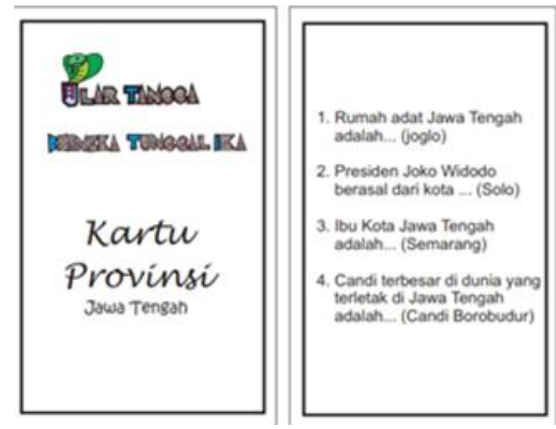

Figure 2 Provincial Card

This snakes and ladder game is very popular with children because they can play it together with friends in the open space while keeping their distance. Juna says "it's nice to be able to play outside because at home it's so bored". Similarly, Abel said that he was happy to be able to play with friends and not be scolded by parents playing outside.

Parents realize that their children have changed due to the influence on them especially from intense interaction and communication. It turns out that the communication style of the parents affects the child's emotional state [14]. This prolonged Covid 19 makes parents depressed due to economic and social limitations so that to make parents not increasingly stressed by the activeness of children, they give gadgets instead. They realize that being a gadget is not good and making them addictive. Parents are also very supportive because they think the child is a little off their device. Like a statement from Ms. Ipeh that said "there is at least time for my son to get off the phone".

Based on the questionnaire, out of 12 respondents, only 3 people said they do not like snakes and ladders because the question is so difficult one of them is Ian. Indeed the question that exists in snakes and ladders is not only a question for a certain age of children but varies because there are rules in the group to consist of different ages but only for ages between 7-12 years. Age differences in one group are carried out to establish cooperation and tolerance and mutual respect between levels of age. Those who are older can provide new understanding and knowledge to the younger and younger willing to accept and work together to solve problems.

This game of snakes and ladders in the rules still considers the existence of protocol covid 19 namely $3 \mathrm{M}$ (wearing a mask, washing hands, and keeping a distance). With the presence of a companion in each group and the leader of the game, conditions can be controlled. Thus parents do not prohibit their children from going out to play with snakes and ladders. Escorts are those teenagers who are appointed to take control of children in play.

According to NAEYC (National Association for the Education of Young Children, (1997), playing is the main tool for children's learning. It is similar to the Indonesian government that has set the principle, "Playing while learning or learning while playing" [15]. Playing that appropriate for the purposes above is playing which has characteristics such as to cause pleasure, spontaneity, motivation of the children themselves, and the rules determined by the children themselves. Playing is an activity that very essential for the growth and development of the physical, social, emotional, intellectual, and spiritual elementary school children. By playing children can get to know their environment, interact, and develop their emotions and imagination well [16].

With physical activity outside, children also become healthier both mentally and physically. They can also develop socially and emotionally. As for the benefits of playing in children [17]:

1. Development of physical aspects. The limb gets a chance to be moved, the child can channel excessive energy, so that he does not feel restless. Thus the muscles of the body will grow stronger.

2. Development of rough and smooth motor aspects. 
3. Development of social aspects. He will learn about the value system, habits, and moral standards embraced by society [18].

4. Development of emotional or personality aspects. The child gets the opportunity to release the tension experienced, the feeling of distress, and channel the urges that appear in him. It will at least relax the child.

5. Development of cognition aspects. The child learns basic concepts, develops copyright, understands the words spoken by his friends.

6. Sharpening the sharpness of sense, making the child creative, critical, and not an indifferent child to the events around him.

7. As a therapeutic medium, during play, the behavior of children will appear free and play is something that is naturally already owned by a child.

8. As a medium of intervention, to train certain abilities and often used to train concentration on a particular task, train basic concepts.

The results of the questionnaire describe the benefits felt by children when playing: Feeling of happiness $100 \%$, Increased knowledge $75 \%$, Healthier $83,33 \%$, and more friends $50 \%$.

As for the other changes felt by the child as said by Satria that "the play needs to be patient all want to be true on its own, my group needs to learn compact and willing to relent". The same is stated by Adnan that "we so learn a lot about diversity, such as tolerance and not disappointed kalua times we can not answer like a guess the style or fit the wrong piece of the puzzle". Thus many things that children can get from this game, especially for social and emotional development children have new references about the ability to cooperate, appreciate, be patient, hold back anger, and complement each other. Those who lose also, learn the meaning of failure that in every race there must be a win and a loss.

Snake and ladder game is stated for elementary school children and can accurately answer the fun when playing it [19]. Therefore, this game was created and designed so that children can still play and learn without fear of the Covid 19 virus. Not only that, but this game is effective for children's socio-emotional development. Although this statement needs further and in-depth research.

\section{CONCLUSION}

Outdoor snakes and ladders games are very useful and play a role in the social and emotional development of the child although not significantly changed immediately. However, from playing snakes and ladders they learn to develop their social and emotional attitudes and behaviors such as respect, tolerance, cooperation, and caring. This game of snakes and ladders is quite effective for the social and emotional development of children because the snakes and ladders contain the value of unity and unity, played in groups, and related to relationships between communities. This game can stimulate children to work together, respect each other, and tolerate.

\section{AUTHORS' CONTRIBUTIONS}

The role of the researcher here is not only as a researcher but also as the owner of ideas to develop children's games and also at the same time design special games during the covid 19 periods. This game has also been tested by researchers.

\section{ACKNOWLEDGMENTS}

Researchers would like to thank Semarang State University, especially the Faculty of Social Sciences, for providing the opportunity to implement higher education tri dharma. Also, thank you for the moral support, facilities, and infrastructure that have been provided to facilitate the running of the research. Lastly, thank you to Green Village who has openly welcomed the arrival of researchers to carry out research and community service.

\section{REFERENCES}

[1] D. Davina, "Tak Terapkan Lockdown Pemerintah Kampanyekan Social Distancing, Apa Bedanya? Kompas TV,” 2020.

[2] D. Romi, "Pemerintah Terapkan Social Distancing Ketimbang Lockdown. Sumeks. Co," 2020

[3] I. Ismaniar and S. Utoyo, "'Mirror of Effect' dalam Perkembangan Perilaku Anak pada Masa Pandemi Covid 19," Diklus J. Pendidik. Luar Sekol., vol. 4, no. 2, pp. 147-157, 2020.

[4] L. T. S. Jati and W. Sumarni, "Dampak Pandemi Covid-19 Terhadap Perkembangan Anak Sekolah Dasar," 2020, vol. 3, no. 1, pp. 776-783.

[5] I. Fauziah, E. Ernita, D. R. Octavia, and M. Dwiyanti, "Analisis Gangguan Psikososial Dan Emosional Aud Di Ra Nurul Iman Medan Belawan Selama Pembelajaran Berbasis Daring," Kumara Cendekia, vol. 8, no. 3, pp. 316-330, 2020. 
[6] L. Uce, "The golden age: Masa efektif merancang kualitas anak," Bunayya J. Pendidik. Anak, vol. 1, no. 2, pp. 77-92, 2017.

[7] N. W. Wardhani, "The Effectiveness of Distance Learning for Elementary School," 2020, pp. 114-119.

[8] G. W. Saputra, M. A. Rivai, M. Su'udah, S. L. G. Wulandari, T. R. Dewi, and F. Fitroh, "Pengaruh Teknologi Informasi Terhadap Kecerdasan (intelektual, spiritual, emosional dan sosial) studi kasus: anak-anak," Stud. Inform. J. Sist. Inf., vol. 10, no. 2, 2017.

[9] R. Robbiyah, D. Ekasari, and R. Witarsa, "Pengaruh Pola Asuh Ibu terhadap Kecerdasan Sosial Anak Usia Dini di TK Kenanga Kabupaten Bandung Barat," J. Obsesi J. Pendidik. Anak Usia Dini, vol. 2, no. 1, pp. 76-84, 2018.

[10] A. Asrori, T. Hidayat, and A. A. Nugroho, "Hubungan Kecerdasan Emosi dan Interaksi Teman Sebaya Dengan Penyesuaian Sosial Pada Siswa Kelas VIII Program Akselerasi Di SMP Negeri 9 Surakarta," Wacana, vol. 2, no. $1,2010$.

[11] N. Nurjannah, "Mengembangkan Kecerdasan Sosial Emosional Anak Usia Dini Melalui Keteladanan," Hisbah J. Bimbing. Konseling Dan Dakwah Islam, vol. 14, no. 1, pp. 50-61, 2017.

[12] F. Faliyandra, Tri Pusat Kecerdasan Sosial" Membangun Hubungan Baik Antar Manusia Pada Lingkungan Pendidikan di Era Teknologi". Literasi Nusantara, 2019.

[13] A. S. Syarifudin, "Impelementasi pembelajaran daring untuk meningkatkan mutu pendidikan sebagai dampak diterapkannya social distancing," J. Pendidik. Bhs. Dan Sastra Indones. Met., vol. 5, no. 1, pp. 31-34, 2020.

[14] J. A. Lambie and A. Lindberg, "The role of maternal emotional validation and invalidation on children's emotional awareness," Merrill-Palmer Q. 1982-, vol. 62, no. 2, pp. 129-157, 2016.
[15] S. L. Santoso and I. Hidayat, "Snake And Lader Cultural (Slc) Game: An Effort To Introduce Cultural Differences To Elementary School Students," ICERI2014, p. 82, 2014.

[16] R. D. Simon, "Model Permainan Di Sekolah Dasar Berdasarkan Pendekatan DAP," 2007.

[17] A. Zellawati, "Terapi bermain untuk mengatasi permasalahan pada anak," Maj. Ilm. Inform., vol. 2, no. 3, 2011.

[18] E. Ibam, T. Adekunle, and O. C. Agbonifo, "A moral education learning system based on the snakes and ladders game," EAI Endorsed Trans. E-Learn., vol. 5, no. 17, 2018.

[19] A. D. Savitri, K. Laksono, D. Rhubido, M. Pramono, I. H. Susanto, and R. Tyasnurita, "Development of Language-Games Snakes and Ladders for Fun," 2020, pp. 1073-1077 